\section{Establishing Lettuce Leaf Nutrient Optimum Ranges Through DRIS Analysis}

\author{
Timothy K. Hartz ${ }^{1}$ and P. R. Johnstone \\ Department of Plant Sciences, University of California, 1 Shields Avenue, \\ Davis, CA 95616

\section{E. Williams \\ Betteravia Farms, 1385 Sinton Road, Santa Maria, CA 93454}

\section{R.F. Smith \\ University of California Cooperative Extension, 1432 Abbott Street, Salinas, CA 93901}

Additional index words. tissue testing, nutrient sufficiency range, soil fertility, Lactuca sativa L.

\begin{abstract}
A survey of 78 commercial iceberg and romaine lettuce (Lactuca sativa L.) fields in the coastal valleys of central California was conducted in 2004-2005. Whole leaf samples were collected at early heading and again within 1 week of harvest. Diagnosis and Recommendation Integrated System (DRIS) leaf concentration norms were calculated for $\mathrm{N}, \mathrm{P}, \mathrm{K}, \mathrm{Ca}, \mathrm{Mg}, \mathrm{S}, \mathrm{B}, \mathrm{Zn}, \mathrm{Mn}, \mathrm{Fe}$, and $\mathrm{Cu}$. Iceberg and romaine lettuce had sufficiently similar leaf nutrient concentrations that the data were combined in the DRIS calculations. Optimum leaf nutrient ranges were developed using data from high-yield fields in which all nutrients were in balance according to the DRIS approach. The DRISderived optimum ranges for $K$ and $C a$ were substantially lower than previously published leaf sufficiency ranges, whereas for the other nutrients, the DRIS optimum ranges were in close agreement. $\mathrm{Cu}$ was the nutrient most frequently below the optimum range in low-yield fields. Comparison of leaf nutrient concentrations with soil nutrient availability and grower fertilization practices suggested that significant improvement in fertilizer management was possible.
\end{abstract}

The coastal valleys of central California produce more than 60,000 ha of lettuce annually, accounting for more than half of the nation's supply. Significant changes have occurred in the industry over the past decade; newer cultivars, increased planting density, and the widespread use of drip irrigation are among the factors that have increased average yields and led to modified fertilization practices. Considerable research on $\mathrm{N}$ and $\mathrm{P}$ fertilization of lettuce in this region has been conducted in recent years (Breschini and Hartz, 2002; Hartz et al., 2000; Johnstone et al., 2005). This research called into question the validity of the plant tissue nutrient sufficiency ranges currently used by the industry (Lorenz and Tyler, 1983: Ludwick, 2002).

Foliar nutrient sufficiency guidelines have often been developed from limited numbers of fertilization trials in which typically only one or two nutrients have been manipulated. That approach may not adequately reflect the influences of the wide range in soil characteristics and environmental conditions that char-

Received for publication 17 July. 2006. Accepted for publication 25 Aug. 2006.

We acknowledge the support of the California Department of Food and Agriculture Fertilizer Research and Education Program (FREP)

${ }^{1}$ To whom reprint requests should be addressed; e-mail tkhartz@ucdavis.edu. acterize a regional industry. Furthermore, the interaction among the various macro- and micronutrients is not easily captured by traditional fertilizer trials.

An alternative approach to the development of foliar nutrient sufficiency guidelines is the Diagnosis and Recommendation Integrated System (DRIS; Beaufils, 1973). In the DRIS approach, differences in nutrient concentrations and nutrient ratios between high- and low-yielding populations are used to estimate the degree to which various nutrients may limit yield either by deficiency or excess (Walworth and Sumner, 1987). DRIS evaluation criteria have been developed for a range of agronomic and horticultural crops (Angeles et al., 1990; Beverly et al., 1984; Elwali et al., 1985; Parent and Granger, 1989; Walworth et al., 1986), including lettuce (Sanchez et al., 1991). DRIS was originally conceived as a diagnostic tool with which tissue nutrient concentrations in a field of interest could be compared with a set of established standards, or "norms", through the calculation of nutrient indices; these indices would rank the relative degree of deficiency or excess for each nutrient. However, the complexity of this system has limited its practical application within the commercial horticultural industry.

The DRIS framework for comparing the nutrient concentration differences between high- and low-yielding populations can also be used to establish optimum leaf nutrient ranges (Needham et al., 1990). Hartz et al. (1998) used DRIS analysis to calculate leaf nutrient norms for processing tomato ( $\mathrm{LycO}-$ persicon esculentum Mill.) and used those norms and the variance in nutrient concentrations among high-yield fields to establish leaf nutrient optimum ranges. The objective of the current study was to apply DRIS analysis to data collected in a survey of commercial lettuce fields to establish whole leaf macro- and micronutrient optimum ranges of broad applicability to the California lettuce industry.

\section{Materials and Methods}

In 2004 and 2005, a total of 35 commercial fields of iceberg and 43 fields of romaine lettuce were sampled in the coastal production regions of central California. Fields were selected to cover the growing season from early Spring through Fall and to represent a range of grower production practices. Composite soil samples (top $30 \mathrm{~cm}$ ) were collected in each field at the start of the season, air-dried, and screened through 2-mm mesh. Soil $\mathrm{pH}$ was determined on saturated paste extracts and organic matter content by a modified Walkley-Black method (Nelson and Sommers, 1982). Soil texture was quantified by the hydrometer method of Sheldrick and Wang (1993). Bicarbonate extraction (Olsen and Sommers, 1982) was used to estimate soil $\mathrm{P}$ availability. Soil-exchangeable $\mathrm{K}, \mathrm{Ca}$, and $\mathrm{Mg}$ were measured by atomic emission spectrometry (AES) following ammonium acetate extraction (Thomas, 1982). DTPAextractable soil $\mathrm{Zn}, \mathrm{Mn}, \mathrm{Fe}$, and $\mathrm{Cu}$ were determined by atomic absorption spectrometry (AAS; Lindsay and Norvell, 1978).

Whole leaf samples were collected at the early heading stage (about midseason) and again within 1 week of harvest (designated the "preharvest" sample). At each growth stage, the youngest wrapper leaf was collected from at least 20 plants. Leaves were rinsed in $0.5 \%$ detergent solution to minimize surface contamination, and then oven-dried and ground for analysis. Total leaf $\mathrm{N}$ was determined by nitrogen gas analyzer (Model FP-528; LECO Corp., St. Joseph, Mich.). Leaf $\mathrm{K}$ concentration was analyzed by AES after extraction in $2 \%$ acetic acid. All other tissue analyses were conducted after microwave digestion with nitric acid and hydrogen peroxide (Sah and Miller, 1992); Zn, Mn, Fe, and $\mathrm{Cu}$ concentration was determined by AAS, and P, S, Ca, Mg, and B by ICP-AES.

Participating growers reported their seasonal fertilization rates and the commercial yield of each field. Additionally, they rated crop quality (good, fair, poor) and noted any field in which the yield did not reflect the productivity of the crop as a result of poor market conditions (saleable product left in the field because of low demand or price), disease, or insect damage. Based on commercial yield and grower quality ratings, the fields were divided into two groups: high-yield fields rated as "good" quality 
and low-yield fields rated as "poor" or "fair" quality. High yield was defined as greater than 2220 cartons/ha for iceberg lettuce and 2470 cartons/ha for romaine. Although lettuce mass per carton varies based on the type of pack, the industry average is $\approx 22$ and 17 $\mathrm{kg}$ for iceberg and romaine, respectively. Low yield was defined as less than 1970 or 2220 cartons/ha for iceberg lettuce and romaine, respectively. Data from fields of intermediate yield and fields in which yield was affected by market conditions or other nonnutrient-related factors were eliminated from further use.

The mean and variance for each foliar nutrient concentration and the three possible mathematical expressions relating each pair of nutrients (i.e., N/P, P/N, N*P) were calculated for both yield groups at both growth stages. The expression that maximized the ratio low-yield variance/high-yield variance was determined for each growth stage, and the high-yield mean of that expression was selected as the DRIS norm for that nutrient pair. Nutrient pairs for which none of the mathematical expressions given an $\mathrm{F}>1.0$ were omitted from further analysis.

A DRIS index for each nutrient was calculated for each field using the method of Walworth and Sumner (1987). In short, the relative abundance of each nutrient was evaluated by comparing all expressions containing that nutrient (i.e., $\mathrm{N} / \mathrm{P}, \mathrm{N} * \mathrm{~K}, \mathrm{Ca} / \mathrm{N}$, and so on) with the corresponding DRIS norms; the DRIS index is the sum of these comparisons. In theory, an index value of zero would indicate an optimum level of a nutrient, but in practice, an optimum range is more appropriate. Following the precedent of Beaufils (1973), a nutrient index within 1.33 standard deviations (SDs) of the high-yield group's zero index value was considered to be balanced and sufficient for high-yield production; \pm 1.33 SD would encompass $\approx 80 \%$ of high-yield fields, assuming a normal distribution. High-yield fields were then evaluated for overall nutrient balance defined as having all nutrient indices within 1.33 SD of the group's zero index value.

\section{Results and Discussion}

A wide range of soil characteristics was encountered in the monitored fields (Table 1). In general, soils were moderately alkaline with relatively low organic matter and high $\mathrm{P}$ and $\mathrm{K}$ availability. Seasonal fertilizer application averaged 184,19 , and $26 \mathrm{~kg} \cdot \mathrm{ha}^{-1} \mathrm{~N}, \mathrm{P}$, and $\mathrm{K}$, respectively, but varied widely among fields; application rates ranged from 30 to $440 \mathrm{~kg} \cdot \mathrm{ha}^{-1} \mathrm{~N}, 0-54 \mathrm{P}$, and 0-78 $\mathrm{K}$. There were 29 high-yield and 25 low-yield fields. High-yield fields averaged 2370 and 3040 cartons/ha for iceberg lettuce and romaine, respectively; the low-yield average was 1460 cartons/ha for both crops. The Shapiro Wilk test confirmed that the yields of the 54 fields used in the DRIS analysis were normally distributed.

Minimal differences in leaf nutrient concentrations between lettuce types were found

Table 1. Range of initial soil characteristics (top 30-cm depth) in the fields sampled for DRIS analysis.

\begin{tabular}{lcccc}
\hline Characteristic & Unit & Mean & Minimum & Maximum \\
\hline pH & $\%$ & 7.3 & 6.6 & 8.0 \\
Organic matter & $\%$ & 1.6 & 0.7 & 4.5 \\
Sand & $\%$ & 44 & 8 & 82 \\
Silt & $\%$ & 33 & 12 & 53 \\
Clay & 23 & 6 & 68 \\
Exchangeable $\mathrm{K}$ & $\mathrm{cmol} \cdot \mathrm{kg}^{-1}$ & 0.73 & 0.22 & 2.53 \\
Exchangeable Ca & $\mathrm{cmol} \cdot \mathrm{kg}^{-1}$ & 15.1 & 5.6 & 36.5 \\
Exchangeable $\mathrm{Mg}$ & $\mathrm{cmol} \cdot \mathrm{kg}^{-1}$ & 4.7 & 1.5 & 15.2 \\
Exchangeable Na & $\mathrm{cmol} \cdot \mathrm{kg}^{-1}$ & 0.7 & 0.2 & 2.4 \\
Extractable $\mathrm{NO}_{3}-\mathrm{N}$ & $\mathrm{mg} \cdot \mathrm{kg}^{-1}$ & 33 & 4 & 141 \\
Extractable $\mathrm{P}$ & $\mathrm{mg} \cdot \mathrm{kg}^{-1}$ & 67 & 19 & 10.6 \\
Extractable $\mathrm{Zn}$ & $\mathrm{mg} \cdot \mathrm{kg}^{-1}$ & 2.9 & 0.5 & 53.8 \\
Extractable $\mathrm{Mn}$ & $\mathrm{mg} \cdot \mathrm{kg}^{-1}$ & 16.3 & 3.5 & 51.3 \\
Extractable $\mathrm{Fe}$ & $\mathrm{mg} \cdot \mathrm{kg}^{-1}$ & 18.4 & 6.7 & 11.6 \\
Extractable $\mathrm{Cu}$ & $\mathrm{mg} \cdot \mathrm{kg}^{-1}$ & 2.7 & 0.7 &
\end{tabular}

(Fig. 1). Therefore, DRIS analysis was performed on the combined iceberg and romaine data. Leaf nutrient concentrations varied between growth stages with $\mathrm{N}$ and $\mathrm{P}$ declining and $\mathrm{K}, \mathrm{Ca}, \mathrm{Mg}$, and $\mathrm{B}$ increasing between the early heading and preharvest samples (Fig. 2). For most nutrient pairs, there was no ratio or product that consistently discriminated between yield groups $(\mathrm{F}>1.0)$ and remained relatively numerically constant across growth stages. Therefore, separate DRIS norms were developed for each growth stage. Table 2 lists the mean leaf nutrient concentrations for high-yield fields (the DRIS norms for the nutrient/dry matter ratios); DRIS norms developed in Florida for iceberg lettuce at early heading (Sanchez et al., 1991) have also been included for comparison. The Florida norms were marginally lower for $\mathrm{N}$ and $\mathrm{P}$, and much higher for $\mathrm{K}, \mathrm{Ca}$, and $\mathrm{Mg}$.

All nutrients were in balance in 12 and 13 high-yield fields at the early heading and preharvest stages, respectively. Using only these "balanced" fields, the linear regression relationship between each DRIS nutrient index and the respective leaf nutrient concentration was calculated. All regressions were significant at $P<0.05$ with the exception of $\mathrm{N}$ at both growth stages and $\mathrm{B}$ at the preharvest stage. From the significant regressions, an optimum leaf nutrient concentration range was calculated, defined as the range corresponding to the zero value of the DRIS index, $\pm 1.33 \mathrm{SD}$ of that nutrient concentration in balanced, high-yield fields. With this statistical approach, $\approx 80 \%$ of high-yield fields would be expected to fall within the range. For $\mathrm{N}$ and preharvest $\mathrm{B}$, the optimum range was defined simply as the mean value \pm 1.33 SD of the balanced, high-yield fields.

The DRIS optimum ranges for $\mathrm{N}$ and $\mathrm{P}$ were in general agreement with previously published sufficiency ranges (Table 3). However, for $\mathrm{K}, \mathrm{Ca}$, and $\mathrm{Mg}$, there was wide variation among references regarding sufficiency levels with the DRIS optimum ranges among the lowest values. The upper limit of the DRIS Ca range was below the lower limit of all other references; the highest leaf $\mathrm{Ca}$ encountered in this study was 11.8 and 14.1 $\mathrm{g} \cdot \mathrm{kg}^{-1}$ at the early heading and preharvest stages, respectively. DRIS optimum micro-

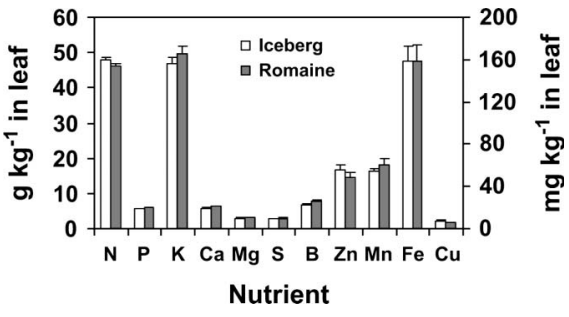

Fig. 1. Comparison of leaf nutrient concentrations between iceberg and romaine lettuce fields. B, $\mathrm{Zn}, \mathrm{Mn}, \mathrm{Fe}$, and $\mathrm{Cu}$ in $\mathrm{mg} \cdot \mathrm{kg}^{-1}$; all other nutrients in $\mathrm{g} \cdot \mathrm{kg}^{-1}$. Bars indicate standard error.

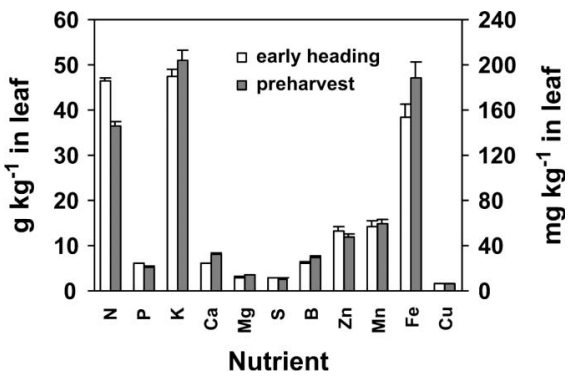

Fig. 2. Mean leaf nutrient concentrations at early heading and preharvest growth stages; data represent all iceberg and romaine lettuce fields sampled. Bars indicate standard error.

nutrient ranges were similar to the established sufficiency ranges with the exception of $\mathrm{Fe}$, which was higher in the DRIS range (Table 4). Both Hochmuth et al. (1991) and Jones et al. (1991) differentiated between iceberg and romaine sufficiency ranges, whereas in this study, the leaf nutrient concentrations were nearly identical between the two lettuce types.

The discrepancy between the DRIS optimum ranges developed in this study and those developed in Florida highlight the difficulty of applying tissue nutrient standards developed under dissimilar soil and environmental conditions. At early heading, none of the high-yield fields had leaf $\mathrm{K}$ as high as the $96.4 \mathrm{~g} \cdot \mathrm{kg}^{-1}$ DRIS norm reported by Sanchez et al. (1991), and less than $40 \%$ of high-yield fields had $\mathrm{K}$ as high as the less restrictive sufficiency threshold of $50 \mathrm{~g} \cdot \mathrm{kg}^{-1}$ suggested by Hochmuth et al. (1991). 
Table 2. DRIS nutrient norms for lettuce: Florida norms for iceberg lettuce, California norms for iceberg and romaine.

\begin{tabular}{|c|c|c|c|c|}
\hline \multirow[b]{2}{*}{ Nutrient } & \multirow[b]{2}{*}{ Unit } & \multicolumn{2}{|c|}{ California DRIS Norms } & \multirow{2}{*}{$\begin{array}{c}\text { Florida DRIS Norms }{ }^{2} \\
\text { Early Heading } \\
\end{array}$} \\
\hline & & Early Heading & Preharvest & \\
\hline $\mathrm{N}$ & $\mathrm{g} \cdot \mathrm{kg}^{-1}$ & 46.4 & 38.1 & 38.7 \\
\hline$P$ & $\mathrm{~g} \cdot \mathrm{kg}^{-1}$ & 6.3 & 5.5 & 4.7 \\
\hline $\mathrm{K}$ & $\mathrm{g} \cdot \mathrm{kg}^{-1}$ & 48.4 & 56.7 & 96.4 \\
\hline $\mathrm{Ca}$ & $\mathrm{g} \cdot \mathrm{kg}^{-1}$ & 5.8 & 8.5 & 16.2 \\
\hline $\mathrm{Mg}$ & $\mathrm{g} \cdot \mathrm{kg}^{-1}$ & 2.9 & 3.4 & 5.4 \\
\hline $\mathrm{S}$ & $\mathrm{g} \cdot \mathrm{kg}^{-1}$ & 2.9 & 2.8 & \\
\hline B & $\mathrm{mg} \cdot \mathrm{kg}^{-1}$ & 24 & 31 & 31 \\
\hline $\mathrm{Zn}$ & $\mathrm{mg} \cdot \mathrm{kg}^{-1}$ & 56 & 47 & 58 \\
\hline $\mathrm{Mn}$ & $\mathrm{mg} \cdot \mathrm{kg}^{-1}$ & 53 & 63 & 53 \\
\hline $\mathrm{Fe}$ & $\mathrm{mg} \cdot \mathrm{kg}^{-1}$ & 164 & 178 & 175 \\
\hline $\mathrm{Cu}$ & $\mathrm{mg} \cdot \mathrm{kg}^{-1}$ & 7.0 & 6.5 & 9.6 \\
\hline
\end{tabular}

${ }^{2}$ From Sanchez et al. (1991); norm for S not given.

Table 3. Comparison of DRIS-derived leaf macronutrient optimum ranges for lettuce with published nutrient sufficiency ranges.

\begin{tabular}{|c|c|c|c|c|c|c|c|}
\hline \multirow[b]{2}{*}{ Growth stage } & \multirow[b]{2}{*}{ Source } & \multicolumn{6}{|c|}{$\begin{array}{c}\text { Leaf Nutrient } \\
\text { Optimum Range }\left(\mathrm{g} \cdot \mathrm{kg}^{-1}\right)\end{array}$} \\
\hline & & $\mathrm{N}$ & $P$ & $\mathrm{~K}$ & $\mathrm{Ca}$ & $\mathrm{Mg}$ & $\mathrm{S}$ \\
\hline \multirow[t]{4}{*}{ Early heading } & DRIS & $43-56$ & $4.5-7.5$ & $33-64$ & $4.5-7.5$ & $2.5-4.0$ & $2.5-3.5$ \\
\hline & Ludwick (2002) & $30-40$ & $4.0-8.5$ & $30-40$ & $14-30$ & & \\
\hline & $\begin{array}{l}\text { Hochmuth et al. (1991), } \\
\text { iceberg }\end{array}$ & $40-50$ & $4.0-6.0$ & $50-70$ & $10-20$ & $3.0-5.0$ & $>3.0$ \\
\hline & $\begin{array}{l}\text { Hochmuth et al. (1991), } \\
\text { romaine }\end{array}$ & $50-60$ & $3.5-8.0$ & $50-60$ & $20-30$ & $2.5-3.5$ & \\
\hline \multirow[t]{6}{*}{ Preharvest } & DRIS & $33-48$ & $3.5-7.5$ & $29-78$ & $6-11$ & $2.5-4.5$ & $2.0-3.5$ \\
\hline & Ludwick (2002) & $25-30$ & $3.5-8.0$ & $30-50$ & $14-30$ & & \\
\hline & $\begin{array}{l}\text { Jones et al. (1991), } \\
\text { iceberg }\end{array}$ & $38-50$ & $4.5-6.0$ & $66-90$ & $15-23$ & $3.6-5.0$ & \\
\hline & $\begin{array}{l}\text { Jones et al. (1991), } \\
\text { romaine }\end{array}$ & $35-45$ & $4.5-8.0$ & $55-62$ & $20-28$ & $6.0-8.0$ & \\
\hline & $\begin{array}{l}\text { Hochmuth et al. (1991), } \\
\text { iceberg }\end{array}$ & $20-30$ & $2.5-5.0$ & $25-50$ & $14-20$ & $3.0-7.0$ & $>3.0$ \\
\hline & $\begin{array}{l}\text { Hochmuth et al. (1991), } \\
\text { romaine }\end{array}$ & $35-45$ & $3.5-6.0$ & $50-60$ & $20-30$ & $2.5-4.0$ & \\
\hline
\end{tabular}

Table 4. Comparison of DRIS-derived leaf micronutrient optimum ranges for lettuce with published nutrient sufficiency ranges.

\begin{tabular}{|c|c|c|c|c|c|c|}
\hline \multirow[b]{2}{*}{ Growth stage } & \multirow[b]{2}{*}{ Source } & \multicolumn{5}{|c|}{$\begin{array}{c}\text { Leaf Nutrient } \\
\text { Optimum Range }\left(\mathrm{mg} \cdot \mathrm{kg}^{-1}\right)\end{array}$} \\
\hline & & B & $\mathrm{Zn}$ & $\mathrm{Mn}$ & $\mathrm{Fe}$ & $\mathrm{Cu}$ \\
\hline \multirow[t]{3}{*}{ Early heading } & DRIS & $19-31$ & $21-75$ & $37-73$ & $86-232$ & $5.6-8.2$ \\
\hline & $\begin{array}{l}\text { Hochmuth et al. (1991), } \\
\text { iceberg }\end{array}$ & $15-30$ & $25-50$ & $20-40$ & $50-150$ & $5-10$ \\
\hline & $\begin{array}{l}\text { Hochmuth et al. (1991), } \\
\text { romaine }\end{array}$ & $30-45$ & $20-50$ & $15-25$ & & $5-10$ \\
\hline \multirow[t]{5}{*}{ Preharvest } & DRIS & $24-36$ & $25-73$ & $45-74$ & $115-257$ & $5.0-8.6$ \\
\hline & $\begin{array}{l}\text { Jones et al. (1991), } \\
\text { iceberg }\end{array}$ & $23-50$ & $25-250$ & $25-250$ & $50-100$ & $7-25$ \\
\hline & $\begin{array}{l}\text { Jones et al. (1991), } \\
\text { romaine }\end{array}$ & $25-60$ & $20-250$ & $11-250$ & $40-100$ & $5-20$ \\
\hline & $\begin{array}{l}\text { Hochmuth et al. (1991), } \\
\text { iceberg }\end{array}$ & $15-30$ & $25-50$ & $20-40$ & $50-150$ & $5-10$ \\
\hline & $\begin{array}{l}\text { Hochmuth et al. (1991), } \\
\text { romaine }\end{array}$ & $30-45$ & $20-50$ & $15-25$ & & $5-10$ \\
\hline
\end{tabular}

Similarly, not one field in the current study met the leaf $\mathrm{Ca}$ standards set by these other researchers. The cause of these large regional differences was not clear, particularly in light of the dominance of $\mathrm{Ca}$ on the soil cation exchange (on average $>70 \%$; Table 1 ). It is noteworthy that the relative proportions of these cations in leaves was quite similar across growth stages and locations; the molar ratio of the DRIS leaf $\mathrm{K}, \mathrm{Ca}$, and $\mathrm{Mg}$ norms was 1.0:1.6:0.09 in Florida (Sanchez et al., 1991) for the early heading stage, and 1.0:1.2:0.09 and 1.0:1.5:0.10 in this study for the early heading and preharvest stages, respectively.

The DRIS approach as used in this study to develop tissue sufficiency standards has both strengths and weaknesses. Using data from numerous fields selected to represent a wide range of soil, environmental conditions and grower production practices ensured that the sufficiency ranges developed have broad applicability to the regional industry. This survey approach also documented the frequency of apparent nutrient deficiency. $\mathrm{Cu}$ appeared to be the most commonly limiting nutrient; $>40 \%$ of lowyield fields were below the $\mathrm{Cu}$ sufficiency range at both growth stages. Although this did not prove widespread $\mathrm{Cu}$ deficiency, the similarity of leaf $\mathrm{Cu}$ sufficiency levels among all reference sources cited in Table 4 and the fact that the mean extractable soil $\mathrm{Cu}$ level in these fields was far below that reported by Brown and deBoer (1983) to be representative of California soils supported that possibility. Additional research on this point is warranted. There was a statistically significant relationship between soil-extractable $\mathrm{Cu}$ and preharvest leaf $\mathrm{Cu}$ (Fig. 3). However, that relationship was insufficiently strong to set a critical soil $\mathrm{Cu}$ threshold.

A limitation of our survey approach was that without including fields of documented nutrient deficiency in the analysis, the sufficiency ranges for some nutrients may have been higher than required for optimum yield. Possible examples in this study were the $\mathrm{N}$ and $P$ ranges. Widespread overfertilization in California lettuce production has been clearly documented (Breschini and Hartz, 2002; Hartz et al., 2000; Johnstone et al., 2005); these studies have shown that soil $\mathrm{N}$ and $\mathrm{P}$ availability is sufficiently high that many commercial lettuce fields require no fertilization. The likelihood of encountering yieldlimiting $\mathrm{N}$ or $\mathrm{P}$ deficiency in commercial fields in this region is remote. Therefore, leaf $\mathrm{N}$ and $\mathrm{P}$ concentrations within the DRIS optimum ranges can be considered sufficient for high-yield production, but values below these ranges may not represent yield-limiting nutrient deficiency. There were no apparent adverse effects of high $\mathrm{N}$ or $\mathrm{P}$ availability on crop productivity or uptake of other nutrients; the only significant negative correlation observed was between leaf $\mathrm{P}$ and leaf $\mathrm{Mg}$ at the preharvest stage $(r=-0.26)$, yet mean preharvest leaf $\mathrm{Mg}$ was the same for both yield groups $\left(3.4 \mathrm{~g} \cdot \mathrm{kg}^{-1}\right)$.

This field survey approach did provide an opportunity to evaluate the soil fertility

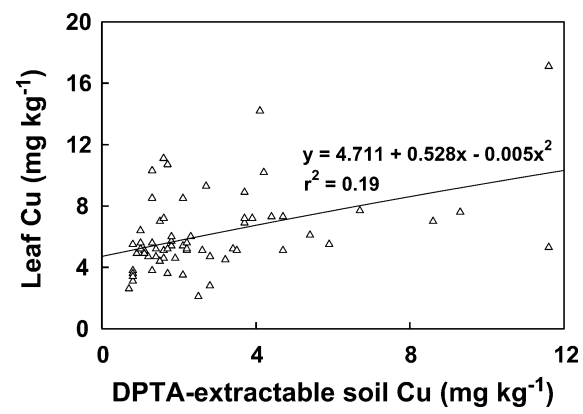

Fig. 3. Relationship between DTPA-extractable soil $\mathrm{Cu}$ and preharvest lettuce leaf $\mathrm{Cu}$; regression significant at $P<0.05$. 

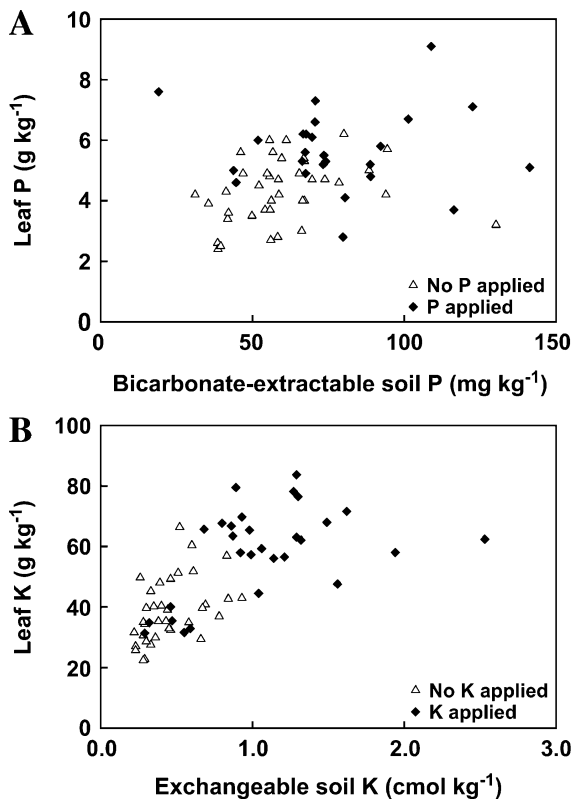

Fig. 4. Relationships among soil test level, grower fertilizer application, and preharvest lettuce leaf nutrient concentration for (A) P and (B) K.

management practices of the coastal lettuce industry. Seasonal $\mathrm{N}$ rate varied among fields by more than $300 \mathrm{~kg} \cdot \mathrm{ha}^{-1}$, but application rate was not correlated with either commercial yield or leaf $\mathrm{N}$ concentration. Preharvest leaf $\mathrm{N}$ was below the DRIS optimum range in nine fields, but only three of these were lowyielding, supporting the possibility that the $\mathrm{N}$ optimum range may be higher than required.

The application of $\mathrm{P}$ or $\mathrm{K}$ was more often based on grower practice than on soil fertility status (Fig. 4). Many growers used a standard fertilization program that was applied to all their fields, regardless of soil test level. That was most clearly observed with $\mathrm{K}$ management. Growers who routinely included $\mathrm{K}$ in preplant fertilization have built up high exchangeable soil $\mathrm{K}\left(>1.0 \mathrm{cmol} \cdot \mathrm{kg}^{-1}\right.$ in many fields); in contrast, the fields of growers who do not routinely apply $\mathrm{K}$ averaged $<0.5$ $\mathrm{cmol} \cdot \mathrm{kg}^{-1}$ with some fields approaching a critical level. For fields in which no $\mathrm{K}$ was applied, a quadratic equation described the relationship between soil $\mathrm{K}$ and preharvest leaf $\mathrm{K}\left(\mathrm{y}=142.8 \mathrm{x}-108.3 \mathrm{x}^{2}, \mathrm{r}^{2}=0.26\right)$. The soil K level corresponding to the lower limit of the DRIS optimum range was 0.25 $\mathrm{cmol} \cdot \mathrm{kg}^{-1}$.

Similarly, the decision to apply $\mathrm{P}$ was often not based on soil testing with P application most common in the fields of highest soil P level. The generally high level of soil $\mathrm{P}$ fertility in this production region was emphasized by the lack of correlation between soil test $\mathrm{P}$ and leaf $\mathrm{P}$ at any growth stage even in fields with no applied P. These results confirm the findings of Johnstone et al. (2005) that $P$ application in high-P soils has no effect on lettuce production.

In summary, data on soil nutrient status, leaf nutrient concentration, and grower fertilizer application rate from 78 commercial lettuce fields allowed the calculation of DRIS optimum leaf nutrient ranges and provided insight on potential improvements in fertilizer management practices. The DRIS optimum nutrient ranges generally confirmed previously published leaf sufficiency ranges for $\mathrm{N}, \mathrm{P}$, and most micronutrients. However, leaf sufficiency ranges for $\mathrm{K}, \mathrm{Ca}$, and $\mathrm{Mg}$ were much lower than those previously reported from Florida, highlighting the danger of using standards developed under different environmental conditions without local confirmation of their validity. An overall reduction in $\mathrm{N}$ application and greater reliance on soil testing to guide $\mathrm{P}$ and $\mathrm{K}$ fertilization was warranted.

\section{Literature Cited}

Angeles, D.E., M.E. Sumner, and N.W. Barbour. 1990. Preliminary nitrogen, phosphorus and potassium DRIS norms for pineapple. HortScience 25:652-655.

Beaufils, E.R. 1973. Diagnosis and Recommendation Integrated System (DRIS). Soil Sci. Bull. 1, Univ. of Natal, South Africa.

Beverly, R.B., J.C. Stark, J.C. Ojala, and T.W. Embleton. 1984. Nutrient diagnosis of Valencia oranges by DRIS. J. Amer. Soc. Hort. Sci. 109:649-654.

Breschini, S.J. and T.K. Hartz. 2002. Presidedress soil nitrate testing reduces nitrogen fertilizer use and nitrate leaching hazard in lettuce production. HortScience 37:1061-1064.

Brown, A.L. and G.J. deBoer. 1983. Soil tests for zinc, iron, manganese and copper. In: H.M. Reisenauer (ed.). Soil and plant tissue testing in California. Univ. Calif. Bulletin 1879

Elwali, A.M.O., G.L. Gascho, and M.E. Sumner 1985. Sufficiency levels and DRIS norms for 11 nutrients in corn. Agron. J. 77:506-508.

Hartz, T.K., W.E. Bendixen, and L. Wierdsma 2000. The value of pre-sidedress soil nitrate testing as a nitrogen management tool in irrigated vegetable production. HortScience 35:651-656.

Hartz, T.K., E.M. Miyao, and J.G. Valencia. 1998. DRIS evaluation of the nutritional status of processing tomato. HortScience 33:830-832.

Hochmuth, G., D. Maynard, C. Vavrina, and E. Hanlon. 1991. Plant tissue analysis and interpretation for vegetable crops in Florida.
Univ. Florida Special Publication SS-VEC42.

Johnstone, P.R., T.K. Hartz, M.D. Cahn, and M.R. Johnstone. 2005. Lettuce response to phosphorus fertilization in high phosphorus soils. HortScience 40:1499-1503.

Jones, J.B., B. Wolf, and H.A. Mills. 1991. Plant analysis handbook. Micro-Macro Publishing, Athens, Ga., 213 pp.

Lindsay, W.L. and W.A. Norvell. 1978. Development of a DTPA soil test for zinc, iron, manganese and copper. Soil Sci. Soc. Amer. J. 42:421-428.

Lorenz, O.A. and K.B. Tyler. 1983. Plant tissue analysis of vegetable crops, p. 24-29. In: H.M. Reisenaur (ed.). Soil and plant tissue testing in California. Univ. Calif. Coop. Ext. Bull 1879.

Ludwick, A.E. (ed.). 2002. Western fertilizer handbook 9th ed. Interstate Publishers, Inc., Danville, Ill., pp. 356.

Needham, T.D., J.A. Burger, and R.G. Oderwald. 1990. Relationship between diagnosis and recommendation integrated system (DRIS) and optima and foliar nutrient critical levels. Soil Sci. Soc. Amer. J. 54:883-886.

Nelson, D.W. and L.E. Sommers. 1982. Total carbon, organic carbon and organic matter, p. 539-579. In: A.L. Page, R.H. Miller, and D.R. Keeney (eds.). Methods of soil analysis: Part 2. Chemical and microbiological properties. ASA Monograph Number 9.

Olsen, S.R. and L.E. Sommers. 1982. Phosphorus, p. 403-430. In: A.L. Page, R.H. Miller, and D.R. Keeney (eds.). Methods of soil analysis: Part 2 Chemical and microbiological properties. ASA Monograph Number 9.

Parent, L.E. and R.L. Granger. 1989. Derivation of DRIS norms from a high density apple orchard established in Quebec Appalachian mountains. J. Amer. Soc. Hort. Sci. 114:915-919.

Sah, R.N. and R.O. Miller. 1992. Spontaneous reaction for acid dissolution of biological tissues in closed vessels. Anal. Chem. 64:230-233.

Sanchez, C.A., G.H. Snyder, and H.W. Burdine. 1991. DRIS evaluation of the nutritional status of crisphead lettuce. HortScience 26:274-276.

Sheldrick, B.H. and C. Wang. 1993. Particle size distribution, p. 499-511. In: M.R. Carter (ed.). Soil sampling and methods of analysis. Can. Soc. Soil Sci., Lewis Publishers, Ann Arbor, Mich.

Thomas,, G.W. 1982. Exchangeable cations, p.159-165. In: A.L. Page, R.H. Miller, and D.R. Keeney (eds.). Methods of soil analysis: Part 2. Chemical and microbiological properties. ASA Monograph Number 9.

Walworth, J.L. and M.E. Sumner. 1987. The diagnosis and recommendation integrated system. Adv. Soil Sci. 6:149-188.

Walworth, J.L., M.E. Sumner, R.A. Isaac, and C.O. Plank. 1986. Preliminary DRIS norms for alfalfa in the southeastern United States and a comparison with Midwestern norms. Agron. J. 78:1046-1052. 